\title{
Research on Experience Model of Precision Poverty Alleviation in S Village-Based on the Perspective of Policy Implementation Process Theory
}

\author{
Yingcong Su \\ School of Public Management, Jinan University, Guangzhou, China \\ Email:yingcong_su@163.com
}

How to cite this paper: Su, Y.C. (2019) Research on Experience Model of Precision Poverty Alleviation in S Village-Based on the Perspective of Policy Implementation Process Theory. Journal of Service Science and Management, 12, 880-898. https://doi.org/10.4236/jssm.2019.127060

Received: November 19, 2019

Accepted: December 23, 2019

Published: December 26, 2019

Copyright $\odot 2019$ by author(s) and Scientific Research Publishing Inc. This work is licensed under the Creative Commons Attribution International License (CC BY 4.0).

http://creativecommons.org/licenses/by/4.0/

(c) (i) Open Access

\begin{abstract}
Overcoming poverty is the top priority of the $13^{\text {th }}$ Five-Year Plan and the key to achieving the first century-long goal of a well-off society in an all-round way. With the continuous advancement of poverty alleviation work in China, the poverty alleviation work has encountered various difficulties, such as "the scattered distribution of poor households, multiple causes of poverty, and inadequate poverty relief", and the effectiveness of poverty alleviation has been weakened. Against this background, General Secretary Xi Jinping made important instructions on "targeted poverty alleviation" and successively introduced related policies on targeted poverty alleviation in the following years, opening a new chapter for China's poverty alleviation. Based on the social background of the "China Highlights, World Model" poverty alleviation effect in Guangdong Province, this paper selects the "S Village in Qingyuan City" to carry out field research, elaborates the existing poverty alleviation projects in S Village, and uses Smith policy to perform theoretical analysis, and analyzes the reasons for its effectiveness. Through analysis, it is found that the reason for the outstanding effect of poverty alleviation in S Village is that the poverty alleviation subjects such as the village poverty alleviation task force made full use of poverty reduction policies support, faced the poor households who were desperate to get rid of poverty, accurately analyzed their causes of poverty, and adopted corresponding poverty alleviation measures to stimulate. The endogenous drive for poverty alleviation of poor households was achieved, and the goal of joint efforts for poverty alleviation was achieved. Finally, this article builds an effective and targeted poverty alleviation system based on the effectiveness of poverty alleviation in S Village.
\end{abstract}


Targeting both sides of poverty alleviation is the foundation, achieving the precise supply and demand of poor households is the key, implementing the responsibility of both sides is fundamental, and using appropriate means of poverty alleviation is the guarantee.

\section{Keywords}

Poverty, Targeted Poverty Alleviation, Policy Implementation, Poverty Alleviation System

\section{Question}

Overcoming poverty is the top priority of the " $13^{\text {th }}$ Five-Year Plan" and the key to achieving the first century-long goal of a well-off society in an all-round way. Since the founding of the People's Republic of China, China's poverty alleviation work has continued to advance, and the targets of poverty alleviation have undergone an orderly transition from "total to regional, and then to regional and individual" [1]. After decades of poverty alleviation work, China has achieved outstanding results. Measured at the current rural poverty standards of the year, the scale of China's rural poor in 1978 was 770 million, and the size of China's rural poor in 2016 was 43.35 million $^{1}$. From 1978 to 2016, China's rural poverty population decreased by 700 million. An average annual poverty reduction of more than 18 million people has made a huge contribution to the global poverty reduction cause. However, with the continuous advancement of poverty alleviation work in our country, poverty alleviation efforts have encountered various difficulties, such as "the scattered distribution of poor households, multiple causes of poverty, and inadequate poverty relief", and the effectiveness of poverty alleviation has been weakened [2]. In November 2013, General Secretary Xi Jinping made the first important instruction of "precision poverty alleviation" during his inspection in Xiangxi, Hunan Province. In January 2014, the "Opinions on Innovative Mechanisms to Solidly Promote Rural Poverty Alleviation and Development" issued by the General Office of the Central Committee of the Communist Party of China and the General Office of the State Council explicitly proposed "establishing a targeted poverty alleviation mechanism" and constructed the top-level design of precision poverty alleviation. Since then, under the support and guidance of the CPC Central Committee's policies, manpower, and funds, various provinces and cities across the country have launched various targeted poverty alleviation efforts. At the end of 2015, President Xi Jinping clearly put forward the five important tasks of national economic and social development in 2016. Among them, the focus was on "adhering to targeted poverty alleviation and targeted poverty alleviation, targeting the poor people who set up files and establishing cards, increasing funding, policies and work, investing in

${ }^{1}$ National Bureau of Statistics. (2016). Statistical Communiqué of the People's Republic of China on National Economic and Social Development 2016. 
efforts to improve the quality of poverty alleviation"; this opinion has important guiding significance for poverty alleviation work in various provinces and cities.

Since 2010, in accordance with a three-year cycle, Guangdong Province has implemented two consecutive rounds of poverty alleviation and development "plan-to-household, responsibility-to-people" actions, which have successively addressed 5978 poor villages, 507,000 poor households, and 2.486 million poor people. The problem of getting rid of poverty and getting rich has strongly promoted the coordinated development and shared development of urban and rural areas in the province ${ }^{2}$. In 2014, Liu Yongfu, the director of the State Council's Poverty Alleviation Office, made a special trip to Guangdong for investigation and summarized Guangdong's poverty alleviation as the "four most", that is, "the highest degree of leadership attention, the most supportive policies, the most capital investment, and the widest social participation." It is a highlight of China and a world model that is worth learning ${ }^{3}$. In 2016, Guangdong issued the "Implementation Opinions on the Three-year Tackling of Targeted Poverty Alleviation and Poverty Alleviation" in the new era, announcing the start of the third round of poverty alleviation work, with the goal of completely solving the remaining 2277 poor villages and 1.94 million poor people, taking the lead to a well-off society in 2018. In the overall progress of poverty alleviation work across the country, why Guangdong's poverty alleviation work has achieved outstanding achievements? Is there an inevitable link between Guangdong's poverty alleviation policy and its effectiveness? What is the role of aid subjects in poverty alleviation? Faced with foreign helpers for poverty alleviation, will the village committee fully cooperate or restrain it? What are the main ways for poor villagers to get rid of poverty? This series of questions aroused the research interest of the author. The author tried to conduct field surveys by selecting $S$ villages with outstanding poverty alleviation effects in the province, and summarized their poverty alleviation experience.

\section{The Case of Precision Poverty Alleviation in S Village}

After the policy is formulated, the effect of the policy needs to be tested during implementation. Since the slogan "Precision Poverty Alleviation" was proposed by the state, governments at all levels including the state, provinces, cities, and counties have continuously introduced poverty reduction policies, while grassroots governments have implemented poverty reduction work. Because the rural area occupies the vast majority of the poor, the effectiveness of each rural poverty alleviation effect will directly affect the progress of poverty alleviation [3]. This chapter first introduces the development of S Village, then explains the existing poverty alleviation work, and finally points out the outstanding achievements of the $S$ village.

${ }^{2}$ South China Network. Precise Poverty Alleviation: Guangdong Experience Becomes "China's Highlight”. Retrieved March 9, 2017, from http://news.southcn.com.

${ }^{3}$ Nanfang daily. Guangdong's "precision poverty alleviation" has become a national experience. Retrieved December 10, 2014, from http://epaper.southcn.com. 


\subsection{Basic Situation of S Village}

S Village is located in the center of S Town, Qingyuan City, with a total area of 9.3 square kilometers and a distance of 32 kilometers from the county seat. It belongs to the Karst landform development zone and limestone alpine mountain area. The village has all achieved access, mail, electricity and water. The village committee has 23 natural villages under its jurisdiction, with an area of 2652 acres of arable land, of which 1023 acres of paddy fields and 1629 acres of dry land. Economic development is dominated by agricultural planting. The agricultural planting distribution is fragmented due to the influence of Karst landforms, and agricultural output is low. S village has 7 village cadres, 63 party members, 6 party branches, 693 peasant households, and a population of 3750 . In 2015, the per capita disposable income of poor households in S village was about 3200 yuan per year, which was a provincial-level poverty village.

\subsection{History of Targeted Poverty Alleviation in S Village}

Beginning in June 2016, under the call of the Guangdong Provincial Party Committee, various government agencies and enterprise units in developed cities and cities set up poverty alleviation teams, and entered the counterpart assistance villages to carry out the third round of poverty alleviation work. The poverty alleviation work of S Village is carried out in this background. This article summarizes the poverty alleviation process of $S$ Village as follows:

\subsubsection{Study Policy Documents and Set up a Poverty Alleviation Task Force}

Under the deployment of the Provincial Party Committee and the Provincial Government, the guidance of the Municipal Party Committee and Municipal Government, and the drive of the District Party Committee and District Government, Guangzhou A, B, and C three bureaus jointly established a poverty alleviation working group to assist S Village. After comprehending the policy ideas, the three bureaus sent cadres $\mathrm{K}$ to settle in $\mathrm{S}$ village, and set up a village poverty alleviation task force with the first secretary and $\mathrm{S}$ village cadres selected by the county where $S$ village was located to work together to solve the problem of poor households. In the poverty alleviation task force, the village cadre was mainly responsible for poverty alleviation, the first secretary was responsible for party building, and the village cadres were responsible for assisting village cadres to carry out poverty alleviation.

\subsubsection{Carry out Object Recognition and File Registration}

In S Village, the poverty alleviation team in the village carried out the identification of poor households through various methods such as bulletin boards of village committees, bulletin boards of village groups, villager group leaders, and household surveys. Among them, the identification process of poor households had gone through the seven major steps of "Village application-Village group centralized voting-Village committee gathering opinions-Village working 
group inspection-Village congress voting-List announcement-Reporting list to town government". According to the provincial poverty line of $4000 \mathrm{yu}-$ an/person/year, after investigation and review, the poverty alleviation team in the village confirmed that there were 64 poor households in S village and 247 poor people, of which the annual per capita disposable income of poor households in S village was about 3200 yuan about. After going through household surveys, data collection, and feedback from villagers, the poverty alleviation task force in the village entered the information of the poor households into the "Guangdong Provincial Poverty Alleviation Information Management System", established a file for the poor households, and implemented dynamic management.

\subsubsection{Develop Poverty Alleviation Plans and Integrate Poverty Alleviation Resources}

Starting in 2016, the third round of poverty alleviation in Guangdong would last three years, and strive to achieve a well-off society in advance in 2018. Therefore, in the process of targeted poverty alleviation, S Village had formulated a three-year master plan and an annual sub-plan, to gradually and respectively advance the poverty reduction work of S Village as planned. The entire planning system clearly pointed out the target tasks and specific plans, and had a significant guiding role in the development of poverty reduction work. In terms of target tasks, the master plan stated that by 2018, the per capita disposable income of the relatively poor people with working capacity would not be less than $45 \%$ (7365 yuan) of the per capita disposable income of rural residents in the province that year; all or Relatively poor people who were partially incapacitated were included in the minimum living security to ensure that all of them achieve stable poverty alleviation; the disposable income per capita of the village was not less than $60 \%$ (9820 yuan) per capita disposable income of rural residents in the province that year. On this basis, the annual target was implemented: in 2016, the poverty-stricken people who had lost all or part of their working capacity in compliance with the policy were included in social security, and all policy guarantees had been adopted to eradicate poverty; in $2017,65 \%$ of the relatively poor population would achieve poverty alleviation; in 2018, 100\% of the relative poor would achieve poverty alleviation.

In addition, help units implemented multi-resource integration. In terms of funding, five aspects of economic resources were integrated: special funds for provincial poverty reduction, self-raised funds by district governments, funds raised by aid units, industry funds, and social love funds. In terms of manpower, they implemented the "planning to households and responsibilities to people" and the "one-to-one responsibility assistance" system. The help units selected 64 leading cadres and established assistance agreements with 64 poor households. Each poverty-stricken household received a help card with personal information and contact phone number printed on the help card. The assistance agreement could only be terminated until the poor households are stably lifted out of poverty. This measure had also stimulated the motivation of leading cadres to a 
certain extent.

\subsubsection{Analyze the Causes of Poverty and Formulate Poverty Alleviation Measures}

According to the interviews with the members of the poverty alleviation task force in the village and the analysis of the data of the poor households, the main reasons for the poverty of the poor households in S village were as follows: First, they were poor due to illness and disability. Some poor family members had serious or long-term chronic diseases, medical expenses and rehabilitation costs for disability were huge. Second, they had low cultural quality and lack of labor. The left-behind villagers in the village were mostly old, weak, sick and disabled, and had a low level of education. It was difficult to engage in high-tech work. Most of them were engaged in agriculture or free-range animals. Third, they had the lack of technology and funding for breeding. It was mainly based on family free-range breeding, with a small scale and low commodity rate, which could not form a scale. Fourth, the agricultural industry had a single structure. They mainly relied on the cultivation of low-value-added crops such as rice and corn to maintain their livelihoods, while the drought on the surface and low integration and effective utilization of land resources.

Based on the availability of labor, S Village's resident work divided 247 poor people and adopted different assistance measures. First, for the poor people who do not had the ability to work, they made policy guarantees to eradicate poverty, including the following aspects: one was to expand the coverage of social security, include all the poor households in the social security system, fund 179 people to participate in urban and rural residents' cooperative medical care, and fund 53 People purchase basic endowment insurance for urban and rural residents. two was to assist undocumented persons with disabilities to obtain a disability certificate so that the disabled could enjoy the social benefits they deserve. Three was to provide education subsidies for school-age children; the subsidy standard was 3000 yuan per person/year, Junior high school 4000 yuan/person/year, high school 7000 yuan/person/year, university 15,000 yuan/person/year. The subsidy was issued by the provincial special fund.

Second, for the poor population with labor force, the main poverty alleviation measures were as follows. One was that the county-level government and the town-level government were contacted to carry out "county-town-village" three-level skills training, of which the county-level town government was responsible for the training of vocational skills such as electricians, starting cars, and childcare. The purpose was to continuously improve the professional literacy of the poor and improve their ability to escape poverty. Two was that the employment assistance was provided by the County Bureau of Human Resources and Social Security, which recommended employment to the poor who were willing to go out to work. Three was that, for the poor people who were only willing to stay in the village, assistance in the breeding industry, manual assistance, and public welfare work were implemented. Among them, the assistance 
in the breeding industry referred to adopting the model of "cooperatives and poor households" to develop livestock and poultry breeding. The village poverty alleviation task force set up three cooperatives, including pig raising, cattle raising, and chicken raising, to promote the development of poor households through cooperatives. By providing technical support, strengthening breeding training and free distribution of seedlings, feed and other services, raising the level of breeding output and achieving stable income growth for poor households. Each poor household could apply to adopt a certain number of chickens, pigs, and cattle according to their own circumstances. The poor households adopted the poultry after signing the breeding value and signing the adoption agreement. After half a year, the poultry poverty alleviation team in the village agreed and assisted in reselling the poultry, and the profits were all their own. The farming risk was borne by the village poverty alleviation task force, and the farming supervision was carried out by the village poverty alleviation task force, so as to prevent short-term interest behaviors such as selling immediately after adoption by poor households. In addition, manual assistance referred to the village poverty alleviation task force contacting outside manufacturers to purchase handmade materials for poor households, and the poor households did manual processing at home and helped households. Public welfare work assistance refered to the relatively old remaining labor population in some of the poor households. S village committees provided a small number of public welfare jobs from the collective income to achieve the goal of "the village has no income".

Third, to carry out asset assistance. Asset assistance in S Village referred to the establishment of photovoltaic power stations, and all the proceeds belonged to the poor households. The S Village photovoltaic power station was located next to Shaba Reservoir in $S$ town. The average annual sunshine hours in this area was between 1200 and 1500 hours. According to the level planned by the industry standard "Solar Resource Evaluation Method", the area was rich in solar energy resources and was suitable for the development of solar energy. The amount of solar radiation met the design requirements of photovoltaic systems and the estimated average annual power generation of this photovoltaic power station was $878,400 \mathrm{KWh}$. According to the price of the PV benchmarking grid-connected electricity price of 0.98 yuan/KWh in the three types of areas in the country, taking into account corporate income tax, company daily operation and maintenance costs, the income of $\mathrm{S}$ village photovoltaic power station remained at Above $8 \%$, the poor could receive power generation dividends of around 3000 yuan each year.

Fourth, to carry out housing assistance. The village poverty alleviation task force encouraged poor households living in mud-brick houses to build their own houses in batches and gave them appropriate subsidies. The subsidy standard for each household was 40,000 yuan, and about 30 square meters could be built on one floor. The subsidy was allocated from the provincial industry funds, and the goal was to help all eligible poor villagers in $\mathrm{S}$ village to complete the renovation 
of dilapidated houses by the end of 2018 .

Fifth, to implement dynamic management for the poor. The main aspects wre as follows. On the one hand, to strengthen management support for poor households, and timely include new poor households in need of help through feedback from village cadres and villagers, and require the poor households that have stably lifted out of poverty to withdraw from the poverty alleviation system and complete the rational allocation of poverty alleviation resources. On the other hand, to strengthen the rate of home video inspections, pay attention to the needs of poor households, and provide them with a way out of poverty.

\subsubsection{Carry out End-of-Year Assessments to Ensure the Effectiveness of Poverty Alleviation}

According to the Provincial Party Committee's poverty reduction documents, individual poverty reduction assessments and collective assessments were conducted at the end of each year. Personal assessment referred to the "Personal Readme" submitted by poverty alleviation cadres, explaining the poverty alleviation situation that the poverty alleviation unit has done during the year. Collective assessment involved provincial assessment, assessment of assisted cities and assessment of assisted cities. At the end of each year, the cities where the villages were being assisted conduct poverty alleviation assessments to understand the effects of poverty alleviation. Immediately afterwards, the city where the unit was assisted conducted a second assessment to review the effectiveness of poverty reduction. Before March of the following year, the Provincial Poverty Alleviation Office conducted random checks on the poverty alleviation reports submitted by the villages, and entrusted third-party social investigation agencies to verify. The verification included the villager satisfaction survey and the effectiveness of the poverty alleviation task force in the village. Among them, the verification of the most pro-poor population is based on the judgement based on the "eight of one super". "Eight and one super" meant that the people living out of poverty had a stable source of income, safe housing, basic medical security, compulsory education, roads, villages, drinking water, electricity, television, and net income exceeded current national poverty reduction standards. From an objective point of view, the verification of poverty alleviation based on a third-party investigation agency was conducive to ensuring the authenticity and persuasiveness of the effect of poverty alleviation.

\subsection{Effect of Poverty Alleviation in S Village}

In the half-year poverty alleviation work, S Village had made outstanding achievements in poverty alleviation. The first was to complete the poverty alleviation target for 2016, and include the poverty-stricken people who had lost all or part of their working capacity in compliance with the policies into social security, and fully implemented policy-based security to eradicate poverty. As of the end of 2016, S Village had realized 71 policy trips to reduce poverty by subsidizing urban and rural medical insurance, endowment insurance, and applying for 
disability subsidies. Secondly, 23 people had been lifted out of poverty through recommended employment. Thirdly, 12 people had been lifted out of poverty through adopting poultry. Judging from the number of people, the original number of poor people in S village was 247. In 2016, there were 106 people out of poverty, and the proportion of people out of poverty was $42.91 \%$. In terms of income, the disposable income of poor households in S Village in 2016 was 5000 yuan, which increased by $50 \%$ compared with the disposable income of poor households in 2015, and the effect of poverty alleviation was outstanding.

\section{Analysis of the Causes of Poverty Alleviation in S Village from the Perspective of Policy Implementation}

By explaining the poverty alleviation work in S village, the author found that the outstanding poverty alleviation effect in $S$ village was the result of multi-party cooperation. The Provincial Party Committee and Provincial Government formulated poverty alleviation targets and poverty alleviation policies, and spurred the local municipal units to carry out targeted assistance to poor villages. Under the call of the poverty alleviation policy, Guangzhou A, B, and C three bureaus jointly established a poverty alleviation working group to provide counterpart assistance to $S$ village and coordinate the village's poverty alleviation affairs. Among them, the assisted projects could meet the poverty-stricken households with different poverty alleviation needs, and stimulated the impetus for poverty-stricken households to emerge from poverty. Therefore, according to the poverty alleviation effect of $S$ village, the author analyzed the reasons for the poverty alleviation effect of $S$ village around the four aspects of the policy system, policy implementation subject, policy target group and policy environment.

\subsection{Policy System: Three Levels of Legal Effect Support, and Five Aspects of Policy Content Are Unified}

In the implementation of targeted poverty alleviation work, governments at all levels had launched various poverty alleviation policies, providing legal protection, institutional norms and work guidance for poverty alleviation workers. These policies had provided strong policy support for targeted poverty alleviation in rural areas. From the perspective of the legal effectiveness of the policy, the three-level government of the "state-province-city" was working together to support the legal system for poverty alleviation. Among them, the central government coordinated, formulated a major policy of poverty alleviation, and grasped the mainstream direction of poverty alleviation. Provincial governments were responsible for the overall responsibility for poverty alleviation and formulated specific poverty alleviation programs. City and county governments implemented poverty alleviation work, and city governments were responsible for policy guidance and coordination of poverty alleviation within the region. For the project, the county-level government assumed the main responsibility for tackling poverty. The three levels of government maintained consistency in the 
direction of poverty alleviation, the lower levels of government undertook and refined the implementation of the tasks of the higher level governments, and maintained consistency in time and content, which largely guaranteed the maximization of the effectiveness of poverty reduction laws.

In terms of policy content, the five aspects of "identification, funding, personnel, supervision, and responsibility" were unified. Firstly, in terms of object identification, clear and precise identification mechanisms were implemented, dynamic management was implemented, and information objects such as the "Guangdong New Age Precision Poverty Alleviation Information Platform" were used to systematically carry out poverty object identification. Secondly, in terms of funding, the provincial special fund for poverty alleviation, industry funds, city and county assistance funds, and social love assistance would be coordinated to ensure the orderly development of poverty alleviation. Thirdly, in terms of personnel, the municipal and county-level counterpart assistance programs were implemented. Municipalities at various levels sent village cadres to work with the local first secretary and village cadres to form a poverty alleviation task force in the village to carry out a three-year poverty alleviation project. Fourthly, in terms of supervision, the supervision and inspection work system was clearly defined. The supervision and inspection work of poverty alleviation and attack was mainly conducted by holding seminars, consulting data, and conducting field investigations, Questionnaire surveys, individual interviews and listening to reports, accepting reports from the masses, random interviews or unannounced visits, etc., while appropriately using the results of third-party assessments to monitor the effectiveness of poverty alleviation and the use of funds. Fifthly, in terms of responsibility, they took the result as the guide, clearly clarified the responsibility of helping the main body, and implemented the system of "not stopping poverty and not stopping assistance". At the same time, the results of poverty alleviation were linked to the performance of the aid units and the main responsible persons. The outstanding results served as an important basis for selecting and appointing cadres. If the results were not well, the province would notify and rectify within a time limit. The main leaders of the cities and counties that had not completed their tasks would be interviewed, and those who failed to acted or falsified must be held accountable in accordance with the Party's discipline and political discipline.

\subsection{Enforcement Subject: Responsible for Promoting Work Attitudes and Motivating the Accountability System}

Any policy needs to be implemented by the executor. Therefore, the executor's own quality level, identification with the policy, attitude to poverty alleviation work, and attention to management level will affect whether the policy can be effectively implemented. In the process of poverty alleviation in S Village, the policy implementation subjects involved included village cadres, village cadres, assistance cadres, persons in charge of aid units, and persons in charge of aided 
units. It was precisely because of the importance attached to the poverty alleviation policies and the mutual support and cooperation of each implementing subject that S Village could achieve outstanding poverty alleviation effects.

After the start of a new round of poverty alleviation work in Guangdong Province, Guangzhou City and Qingyuan City paired for assistance, and governments at all levels in the city conducted in-depth research on poverty alleviation policies. S Village was a provincial-level impoverished village, which was jointly assisted by three district-level bureau units in Guangzhou. After the joint talks of each unit and the bureau meeting of each unit, $\mathrm{K}$ was selected to be the village cadre of $S$ village. $\mathrm{K}$ is from the military, having a decent work style and outstanding work execution ability, and is well recognized by colleagues. After entering the S Village, they formed a poverty alleviation team in the village together with the first secretary $\mathrm{M}$ selected by Qingyuan City and the village cadres in the village to carry out poverty alleviation work in the S Village. In the process of poverty alleviation, the village poverty alleviation task force made full use of its members' advantages, and promoted the management of poverty alleviation with a responsible working attitude. The main manifestations were as follows. First, in policy promotion, the village poverty alleviation task force relied on the village committee bulletin board, bulletin boards of village groups, and meetings of village groups to promote poverty alleviation policies. After confirming the status of the poor households, the village poverty alleviation task force would also visit the poor households every week to carry out new policy publicity to keep abreast of the current situation of the poor households. Second, in the material review, adhere to the "Village application-centralized voting by the village group-village committee to collect opinions-inspection by the village working group-village representative conference voting-list publicity-report to the town government" Review procedures to ensure fairness. While maintaining procedural fairness, they focused on the cultivation of flexibility. After the villager's vote was over, the members of the village's poverty alleviation team would also go to their home to verify the economic situation of the families who had failed, so as to avoid their loss due to personal grievances. Third, in terms of information disclosure, publicity was selected on the bulletin board of the village committee. The publicity content included project budget, project cost, project implementation results and other aspects, so as to maintain the transparency and openness of poverty reduction work. Fourth, in the household survey, members of the poverty alleviation team in the village maintained visiting to 64 poor households at least per week, and went to the poor households to check and inquire in person. At the same time, for the use of poverty alleviation materials, the village poverty alleviation task force was also strictly monitored, and private resale of poor households was strictly prohibited. It was the responsible working attitude of the members of the poverty alleviation team in the village that promoted the effective management of poverty alleviation.

In the provincial-level poverty alleviation documents, the issue of determining 
the responsibilities of the main bodies and units of poverty alleviation had been clarified many times. The identification of poverty alleviation responsibilities was not process-oriented, but rather results-oriented. It implemented the principle of "do not stop poverty and do not stop helping". For poverty alleviation units, the results of poverty alleviation were linked to the performance of the unit. Good results could be an important basis for appointing cadres. Those with poor results will be notified by the province and require rectification within a time limit. Therefore, the leaders of various poverty alleviation units attached great importance to the implementation of poverty alleviation work, and had conducted in-depth village investigations and inspections to ensure the effectiveness of poverty alleviation. Village cadres said that for individuals, the performance of village cadres was also fully linked to the effectiveness of poverty alleviation. If the poverty alleviation task could not be completed within three years, village cadres would continue to stay in the village to carry out poverty reduction work. The same was true for poverty alleviation cadres. Due to the implementation of "one-on-one assistance", the assistance agreement could only be terminated when the poor households were stably lifted out of poverty. In general, the result-oriented accountability system truly implemented the responsibility of poverty alleviation to the main body of poverty alleviation, brought incentives for poverty alleviation to the main body of poverty alleviation, and provided a strong guarantee for poverty alleviation.

\subsection{Target Group: Recognize and Implement Poverty Alleviation Policies and Stimulate Endogenous Motivation for Poverty Alleviation}

Whether a policy can achieve its intended purpose is not entirely determined by the policy maker or policy executor, and is also affected to some extent by the target group. As the target group of targeted poverty alleviation in rural areas, the degree of recognition and investment of poor households and poor people in poverty alleviation policies will greatly affect the effectiveness of policies [4].

In rural poverty alleviation policies, there are both government welfare protection methods and industrial assistance and asset assistance. The author visited the poor households in S village and found that the poor households had a high level of understanding of poverty alleviation policies, and even ordinary villagers were generally aware of poverty alleviation projects. Poor households could also outline the policy objectives, guarantee standards, and reimbursement processes of urban-rural cooperative medical care. Speaking of livestock adoption projects, poor households were even more excited, and even talked about family animal husbandry planning. For these policies, the poor households attributed most of the reasons to supporting cadres such as village cadres. The high-frequency household survey of the poverty alleviation task force in the village had promoted the publicity of the policy in place, strengthened the villagers' understanding of the poverty alleviation policy, and achieved the "symmetry" of the 
poverty relief information of both sides. In addition, the poor households also praised the poverty alleviation projects carried out, believing that the poverty alleviation projects had greatly helped their lives. Involving poor households in labor matters was conducive to stimulating the endogenous impetus of poor households.

\subsection{Policy Environment: The Villagers Are Gentle and Peaceful, and Have a High Degree of External Acceptance}

Any public policy needs to operate in a certain complex environment. The implementation of policy objectives will be affected by the governance environment. Therefore, the environment is a factor that cannot be ignored in the public policy system. The implementation of the targeted poverty alleviation policy at the grassroots level in rural areas is bound to be affected and restricted by the village environment.

S Village belongs to the Karst landform development zone. The main economic development is agricultural planting, and the economic level is relatively low. Based on the situation of agricultural planting based on the surface division, the distribution of family houses is relatively scattered, and the distribution of poor households is characterized by "fragmentation". Precision poverty alleviation, especially one-on-one poverty alleviation, is particularly important. The local people's customs are gentle and peaceful, they mostly use their families as living units, and there are few family unions. They have a high degree of acceptance of foreign affairs. In recent years, young and middle-aged laborers in the village had gone out, and most of the families were mainly the old, the weak, the sick and the disabled. It was difficult to carry out full-scale agricultural planting, which posed a greater challenge to family income. In addition, after the abolition of the agricultural tax in 2006, the public service funds of the village committees decreased sharply, and the welfare support of the village committees for the villagers was also weakened. Therefore, the village's internal poverty alleviation force was poor and urgently needed external assistance and support. The timely entry of external poverty alleviation forces would undoubtedly help solve the poverty alleviation problem of S Village.

\section{How Establish an Efficient and Targeted Poverty Alleviation System?}

\subsection{The Main Body Aimed at Both Sides in Poverty Alleviation is the Foundation}

Achieving precision poverty alleviation is first and foremost. Accuracy of the subject not only requires accurate identification of the needy poor households, but also requires the selection of high-quality help subjects. Appointing highquality aid subjects can effectively promote the orderly development of poverty alleviation work and guarantee its poverty alleviation effect. The foundation of precision poverty alleviation lies in being able to target both parties in poverty 
alleviation and creates a good atmosphere for poverty alleviation.

\subsubsection{Appointing Supporting Entities with Outstanding Performance}

The appointment situation of the main body of assistance directly affects the implementation of poverty alleviation policies and the effect of poverty alleviation, and plays a pivotal role in poverty alleviation. Therefore, it is necessary to appoint leading cadres with high quality and comprehensive ability to help the poor. In the appointment of village cadres, civil servants with grass-roots work experience, strong working ability and high comprehensive quality should be selected to carry out preliminary work training, and do a good job of communication and coordination between village cadres and village cadres to help village cadres integrate quickly. Helping poor villages. In the selection of "one-on-one assistance" poverty alleviation cadres, the ranks of the ranks and the results of the annual performance evaluation should be considered comprehensively, so that higher-ranking cadres and more capable cadres can help the poorer households.

\subsubsection{Improving the Mechanism for Identifying Poor People}

In the initial work of filing and establishing a card, the application procedures for poor households should be strictly regulated. Besides, to listen more to villagers' opinions, strengthen information disclosure, verify the situation of poor households after entering the household, do a good job of explaining to the unselected poor households, maintain good communication relationships with all villagers, and ensure Target effective households of the poor households, and do a good job of collating and collecting the data of the poor households. Furthermore, relying on the geographical advantages and human experience of village cadres, regular and irregular household surveys will be conducted in the implementation of poverty alleviation projects to understand the problem of poverty alleviation in a timely manner and solve new problems for poor households. For families that achieve stable poverty alleviation through employment, promptly guide them out of the poverty relief team. For the new villagers who have entered the poverty-stricken area, they should do a good job in time after passing the application process. At the same time, relying on the "Poverty Alleviation Information Management System" as the information backing, the state of assistance to the poor households is dynamically managed. In general, in the process of identifying poor households, we must make full use of the villagers' cadre's popularity and strengthen the frequency of household surveys in order to do a good job of object identification.

\subsection{Achieving Precise Supply and Demand of Poor Households Is the Key}

On the basis of the accuracy of the main body, the main body of assistance should take corresponding poverty alleviation measures according to the different causes of poverty of the poor, so as to achieve the precise docking of the as- 
sistance resources of the poor households. Only by accurately identifying the causes of poverty and adopting targeted assistance measures to achieve accurate supply and demand of poor households can we grasp the key to accurate poverty alleviation [5].

\subsubsection{Making Clear the Causes of Poverty}

After doing a good job of identifying objects in the early stage, it is necessary to analyze and summarize the causes of poverty among the poor households. Based on the archives of poor households, understand the age distribution, education, family labor, disability, income, etc. of the poor households, and do a good job of "causing poverty due to illness, poverty due to old age, and poverty due to disability" "Poverty types such as poverty caused by lack of labor force," etc., to grasp the main types of poverty and lay the foundation for taking corresponding measures.

\subsubsection{Implementing Multiple Measures to Help the Poor}

Poverty alleviation should not just rely on capital irrigation to achieve shortterm digital poverty alleviation. This will not only increase the financial pressure on poverty alleviation, but also easily cause the poor households to rely on their welfare and increase the inertia of poverty alleviation. The long-term and efficient poverty alleviation measures are to stimulate the endogenous impetus of poor households and rely on long-term poverty reduction mechanisms to achieve poverty alleviation. Therefore, the poor can be classified according to whether they have labor force or not.

For the poor people who lack labor force, to realize financial welfare to get rid of poverty. The first is to provide urban and rural basic medical insurance subsidies for all the poor, including the poor into the medical security system, reducing the medical expenses of the poor, and reducing the degree of returning to poverty due to illness. The second is to purchase old-age insurance for the elderly to achieve comprehensive coverage of old-age benefits. Third, based on the living security of the disabled, applying for a disability certificate for the undocumented disabled, and using the disability subsidy as their own poverty alleviation fund.

For the poor population with labor force, two aspects of poverty alleviation assistance are implemented. On the one hand, employment assistance is provided. Prior to employment, three-level employment skills training at the "county-town-village" level was conducted to improve capacity. Provide corresponding jobs according to the workers' willingness to go out to work. For those who are willing to go out to work, introduce local employment through the local county human resources and social affairs bureau and assistance units; for those who are not willing to go out to work, provide local public welfare posts, such as cleaners. On the other hand, carrying out industrial assistance. Industrial assistance refers to planning for industrial development, encouraging and guiding poor people to use property rights as a link to obtain rent, dividend income and 
labor income through cooperative management and participation in production and labor. Therefore, it is necessary to develop local poultry and livestock breeding cooperatives according to local conditions, and encourage poor households to obtain value-added benefits from livestock breeding through labor.

In the process of poverty alleviation, in addition to integrating poor households into the social security system and promoting employment, a number of supplementary poverty alleviation measures need to be implemented. The first is housing. For mud-brick houses in rural areas, the poverty alleviation team in the Village should timely resettle poor households to avoid security accidents. With the support of the poor households, assist the poor households to apply for provincial subsidies for the housing construction industry and build a safe poverty alleviation environment for the poor households. Secondly, for poor school-age children, education subsidies should be provided according to different school ages to prevent drop-outs due to poverty and allow children to rely on knowledge to escape poverty in the future. Thirdly, for the village to create suitable asset poverty alleviation, such as photovoltaic power generation, so that the "long-term, stable" asset poverty alleviation and "short, flat, fast" breeding and breeding industry combined three-dimensional industry development mode to carry out efficiently. Finally, strengthen village infrastructure construction, such as building street lamps and roads, to create a good poverty alleviation environment for poor households and even poor villages.

\subsection{Implementing the Responsibilities of Both Sides in Poverty Reduction Is Fundamental}

Only by fulfilling the responsibility to the unit and to the individual can the poverty-relief subjects truly clarify their responsibilities, stimulate their own motivation for poverty alleviation, and devote themselves to the cause of poverty alleviation. At the same time, only by strengthening the sense of responsibility of the poverty-stricken subjects and formulating assistance agreements, can the poverty reduction work be effectively carried out and the basic requirements of precision poverty reduction implemented [6].

\subsubsection{Implement the Responsibility of the Main Body of Poverty Alleviation}

In the development of poverty alleviation work, it is necessary to clarify the responsibility relationship between the poverty alleviation subject and the object of assistance, and increase the importance of the poverty alleviation subject. For the unit, the effect of poverty alleviation is linked to the performance of the department. The good effect serves as an important basis for the promotion of cadres, and the report of the poor results is criticized, thereby increasing the attention of unit leaders and promoting the effective financing of unit poverty and other resources. For individuals, the poverty-relief individuals and the poor households are more task-oriented, and the relationship is result-oriented rather than process-oriented. The village cadres and the first secretary can only leave pover- 
ty-stricken villages after completing the poverty alleviation target within three years, and assisting cadres can only lift the assistance agreement between the two parties after helping the poor households achieve stable poverty alleviation. Putting the responsibility of assistance into practice will help stimulate the poverty alleviation motivation of the main body of poverty alleviation.

\subsubsection{Strengthen the Sense of Responsibility of Poor Households in Poverty Alleviation}

In addition to paying attention to the implementation of the responsibilities of poverty alleviation subjects, we should also pay attention to the problem of poverty alleviation of poor households. Poverty alleviation should not only rely on external forces, but also stimulate the endogenous willingness of poor households to escape poverty, so that poor households can improve their ability to escape poverty and prevent them from returning to poverty again. In the assistance project between the assistance subject and the poor households, a support agreement was signed to clarify the poverty relief responsibilities of the poor households. Take industrial poverty alleviation as an example. After the poor households apply for livestock, they need to sign a help agreement and a commitment letter to ensure that they are not resold privately during the breeding period and maintain the profitability of poverty alleviation materials. In addition, the information on poverty reduction projects should be made public, so that poor households can increase their willingness to escape poverty with the witness and help of other villagers, so as to achieve poverty alleviation at an early date.

\subsection{The Use of Appropriate Poverty Alleviation Measures Is a Guarantee}

The use of poverty alleviation measures by the subjects of poverty alleviation will directly affect the effectiveness of poverty alleviation policies. Therefore, the main body of poverty alleviation must adopt different methods of poverty alleviation according to local conditions and people, so as to expand the scope of policy promotion, implement poverty alleviation projects, and ensure the effectiveness of poverty alleviation.

\subsubsection{Use the Plan to Guide Poverty Reduction}

The plan determines the scale and standards for various complex and changeable management activities, not only pointing the direction for control, but also providing a basis for control work. In complex rural poverty alleviation, poverty alleviation plans are especially needed. There are two types of poverty alleviation plans: target plans and project plans. In the target plan, a master plan for poverty alleviation should be formulated, and on this basis, a phased poverty alleviation plan should be formulated to gradually achieve the goal of poverty alleviation. In the project plan, the costs, benefits, risks, and countermeasures of poverty reduction projects should be planned. With the poverty alleviation plan, we can clearly recognize the current poverty alleviation situation, adjust the resources 
for poverty alleviation, and accurately contribute to the poverty alleviation goals.

\subsubsection{Implement Poverty Alleviation through Household Registration}

In terms of policy promotion, although there is a village committee and village leader on the bulletin board, the effect radiation coverage is difficult to cover all the poor households. Coupled with the problems of scattered poor households, disability, and travel difficulties for elderly poor households in some areas, household promotion is particularly important. In the implementation, led by the village cadres, relying on the village cadres' interpersonal circle, to go to the poor households for policy promotion and project development. In addition, household inspections should be carried out at regular and irregular intervals, and the household frequency should not be less than once per week. This will not only ensure that poverty-stricken households continue their poverty alleviation work, but also help strengthen the cadres in the village to understand the timely issues of the poor households and enhance the relationship between the two sides.

\section{Conclusion}

In the context of the continuous advancement of poverty alleviation work in China, S Village of Qingyuan City launched a variety of poverty alleviation measures in 2016 and achieved good results. This good poverty alleviation effect is inseparable from the accurate grasp of poverty alleviation subjects, poverty supply and demand, poverty alleviation responsibilities, and poverty alleviation methods, and it is worth learning from other poor areas. However, there are still some shortcomings in this study. First, the poverty reduction measures in Guangdong Province are basically the same, but there are differences in the effects of poverty reduction. It can be compared with other poor villages in Guangdong Province to further explore other factors that affect the effectiveness of poverty reduction. Second, there are various causes of poverty in China. The topography and humanities in different regions are now quite different. The migration of Guangdong poverty alleviation projects is still questionable. However, Guangdong Province is accurate in terms of poverty alleviation subjects, poverty supply and demand, poverty alleviation, and poverty alleviation methods. Grasping experience is worth learning from.

\section{Conflicts of Interest}

The author declares no conflicts of interest regarding the publication of this paper.

\section{References}

[1] Liu, Y.S., Zhou, Y. and Liu, J.L. (2016) Regional Characteristics of Poverty-Stricken Rural Areas in China and Their Poverty Alleviation Strategies. Proceedings of the Chinese Academy of Sciences, 3, 269-278.

[2] Mo, G.H. (2016) Targeted Poverty Alleviation: Endogenous Reform and Gover- 
nance Breakthrough of China's Poverty Alleviation Development Model. Research on Socialism with Chinese Characteristics, 2, 73-77 + 94 .

[3] Ge, Z.J. and Xing, C.J. (2015) Precise Poverty Alleviation: Connotation, Practical Difficulties and the Explanation of the Reasons-Based on the Investigation of Two Villages in Yinchuan, Ningxia. Guizhou Social Science, 5, 157-163.

[4] Zheng, R.Q. and Wang, Y. (2016) Preliminary Study on the Targeted Poverty Reduction Policy. Finance Research, 2, 17-24.

[5] Chen, S., Pan, H. and Lu, J. (2016) Performance of Precision Poverty Alleviation and Its Influencing Factors: A Case Study Based on the Eastern, Central and Western Regions. China Administration, 9, 88-93.

[6] Yang, Y.Y., Liu, Y.S. and Zhang, Z.W. (2016) Innovations and Suggestions on Precision Poverty Alleviation Policy Based on Typical Surveys. Bulletin of the Chinese Academy of Sciences, 3, 337-345. 